\title{
A REVIEW OF THE LITERATURE AND MEDIA REPORTS OF PATTERNS OF MENTAL HEALTH STIGMA AND ADDRESSING STIGMA IN SLOVENIA UNTIL 2010 PREGLED LITERATURE IN MEDIJSKIH POROČIL O STIGMATIZACIJI LJUDI Z DUŠEVNIMI MOTNAJMI IN O UKREPIH PROTI STIGMI V SLOVENIJI DO LETA 2010
}

Maja Valič ${ }^{1}$, Lee Knifton ${ }^{2}$, Vesna Švab ${ }^{3}$

Prispelo: 17. 12. 2011 - Sprejeto: 5. 6. 2012

Review article

UDC 614:159.96

\begin{abstract}
As part of the ASPEN (Anti-Stigma Programme - European Network) project's Work Package 4 ('Anti-stigma' best practice), Aspen sites were to conduct a literature review on stigma in their country. In Slovenia, besides the peer review publications and reports, we also included all media reports on stigma in the last five years to illustrate the impact of various professional and public initiatives to reduce stigma and discrimination against depression.

The Slovenian report includes several areas of mental health stigma defined through peer reviewed literature and other professional publications.
\end{abstract}

Key words: Slovenia, stigma, depression, suicide

Pregledni znanstveni članek

UDK 614:159.96

\section{Izvleček}

V okviru evropskega projekta ASPEN (Anti Stigma European Network)smo raziskovali dobre prakse delovanja proti stigmatizaciji ljudi z duševnimi motnjami v različnih državah. Sodelavci v projektu so opravili pregled literature o stigmatizaciji $v$ njihovi državi. $V$ Sloveniji smo poleg pregleda znanstvenih revij in poročil vključili tudi medijska poročila o stigmatizaciji v zadnjih petih letih, da bi bolje predstavili vpliv različnih strokovnih in civilnih pobud za zmanjševanje stigmatizacije in diskriminacije depresije pri nas.

Slovensko poročilo je pregled različnih področij stigmatizacije in destigmatizacije iz znanstvenih in drugih strokovnih publikacij.

Ključne besede: Slovenija, stigma, depresija, samomorilnost

\section{INTRODUCTION}

As part of the ASPEN (Anti-Stigma Programme European Network) project's Work Package 4 ('antistigma best practice'), Aspen sites were to conduct a literature review on stigma in their country. In Slovenia, besides the peer review publications and reports we also included all the media reports on stigma in last ten years to illustrate the impact of various professional and public initiatives to reduce stigma and discrimination against depression (before five years).
The Slovenian report includes several areas of mental health stigma defined through peer reviewed literature and other professional publications.

1. NGO programs against stigma

2. The organization of mental health care

3. Suicide in Slovenia, EAAD study

4. INDIGO study

5. Reports on education against stigma

6. Publications of mental health professionals in Slovenia 
In Slovenia there has been little research done on stigma. The national report of the INDIGO study only included 25 people with schizophrenia. Participation in the European Alliance Against Depression (EAAD) will be reported separately. Most of the reported literature is important for mental health prevention and promotion and isn't directly connected to stigma and depression. This introduction deserves to include a historic point of view as stigma and mental illness in Slovenia can only be understood in its social and cultural context. The first public anti-stigma statement in Slovenia dates from 1881 when the first psychiatric hospital was opened with the speech of doctor Karl Bleiweiss saying that people with mental illness are equal to all other people and that all of society should accelerate their social involvement (1). This statement in many ways determined the attitudes of the Slovene psychiatric professions, as well as many other initiatives evolving in the following centuries with the goal of improving the accommodation, employment and participation of people with mental disorders. Slovenia has a rich history of anti-stigma work, in last few years undertaken mostly by nongovernment organizations, who find it harder to get access to financing research work. Their endeavours may only be measured through perceived public interest and the personal responses of patients and carers.

The largest amount of data gathered in this report was derived from the database established by the largest Slovenian NGO working with people with anxiety and depression in Slovenia called DAM (GIVE). They provided us with an almost complete overview of the media reports on anxiety and depression and the antistigma movement.

\section{METHOD}

Peer reviewed articles were searched for in Pubmed, Science Direct, Google Scholar and Virtual Library of Slovenia (Cobiss). We used the following combination of search terms:

Slovenia AND (stigma* OR attitud* OR prejudice* OR stereotype* OR discrimina*)

AND (mental OR Depress* OR Dysthymi* OR Adjustment Disorder* OR Mood Disorder* OR Affective Disorder ${ }^{*}$ OR Affective Symptom*)

AND (Intervention OR Education OR Informatio OR Project).

All search terms were also used in the Slovenian language.

The search resulted in 35 peer reviewed articles. All the retrieved articles are included in the report.

The media and web report search was performed using Najdi.si and Google search using the same combination of terms. The DAM web-page described above was searched separately. The search resulted in 131 media reports. All the reports were checked for relevance and 38 selected after taking into account relevance and duplication. 


\section{FINDINGS}

Table 1. Professional references.

Tabela 1. Strokovna literatura.

\begin{tabular}{|c|c|c|c|c|}
\hline Year & Autor & Title & Source & $\begin{array}{l}\text { Type of } \\
\text { document }\end{array}$ \\
\hline 2000 & Švab V. & Anti stigma program in Slovenia & Psychiatria Danub & article \\
\hline 2002 & Švab V., Tomori M. & Mental Health Services in Slovenia & Int J Soc Psychiatry & article \\
\hline 2002 & $\begin{array}{l}\text { Švab, V., Tomori, M., } \\
\text { Zalar, B., Ziherl, S., } \\
\text { Dernovšek, M. Z., } \\
\text { Tavčar, R. }\end{array}$ & $\begin{array}{l}\text { Community rehabilitation service for patients with } \\
\text { severe psychotic disorders: the Slovene experience }\end{array}$ & Int J Soc Psychiatry & article \\
\hline 2002 & Zorga S. & $\begin{array}{l}\text { Supervision: the process of life-long learning in social } \\
\text { and educational professions }\end{array}$ & $\mathrm{J}$ Interprof Care & article \\
\hline 2002 & $\begin{array}{l}\text { Bilban M., Bilban } \\
\text { Jakopin C. }\end{array}$ & Methadone maintenance treatment and drugs & Coll Antropol, article & article \\
\hline 2003 & Švab V. & Preparing Mental Health Reform in Slovenia & $\begin{array}{l}\text { Int j psychosoc } \\
\text { rehabil }\end{array}$ & article \\
\hline 2003 & $\begin{array}{l}\text { Kocmur M., } \\
\text { Dernovsek M.Z. }\end{array}$ & $\begin{array}{l}\text { Attitudes towards suicide in Slovenia: a cross- } \\
\text { sectional survey }\end{array}$ & Int J Soc Psychiatry & article \\
\hline 2003 & $\begin{array}{l}\text { Bremberg S., Nilstun } \\
\text { T., Kovac V., Zwitter } \\
\text { M. }\end{array}$ & $\begin{array}{l}\text { GPs facing reluctant and demanding patients: } \\
\text { analysing ethical justifications }\end{array}$ & Fam Pract & article \\
\hline 2004 & ŠENT & Proceedings of the Conference Education for Change & $\begin{array}{l}\text { Proceedings and } \\
\text { conference }\end{array}$ & article \\
\hline 2004 & $\begin{array}{l}\text { Wetzels R., Geest } \\
\text { TA., Wensing M., } \\
\text { Ferreira PL., Grol R., } \\
\text { Baker R. }\end{array}$ & $\begin{array}{l}\text { GPs' views on involvement of older patients: an } \\
\text { European qualitative study }\end{array}$ & Patient Educ Couns, & article \\
\hline 2005 & $\begin{array}{l}\text { Mann J.J., Apter A., } \\
\text { Bertolote J. et al. }\end{array}$ & Suicide prevention strategies: a systematic review & JAMA & article \\
\hline 2006 & Cimerman M. & $\begin{array}{l}\text { Presentation of the Slovene Association for Persons } \\
\text { Suffering from } \\
\text { Depression and Anxiety Disorders }\end{array}$ & Med Razgl & article \\
\hline 2006 & $\begin{array}{l}\text { Mirjanic M., Zorko } \\
\text { M., Marusic A. }\end{array}$ & $\begin{array}{l}\text { Samomor je preprecljiv! Kaj pa v Sloveniji? : Suicide } \\
\text { is preventable! What about Slovenia? }\end{array}$ & JAMA - Slov. ed. & article \\
\hline 2006 & Kamin $\mathrm{T}$. & Mental health promotion: a perspective from Slovenia & $\begin{array}{l}\text { Journal of Public } \\
\text { Mental Health }\end{array}$ & article \\
\hline 2007 & $\begin{array}{l}\text { Zalar B., Strbad M., } \\
\text { Svab V. }\end{array}$ & Psychiatric education: does it affect stigma? & Acad Psychiatry & article \\
\hline 2007 & $\begin{array}{l}\text { Marusic A., Mirjanic } \\
\text { M., Bernik B. }\end{array}$ & $\begin{array}{l}\text { Europe evolving towards a region of non-mental } \\
\text { health stigma }\end{array}$ & J Public Health, & article \\
\hline 2007 & Kamin $\mathrm{T}$. & $\begin{array}{l}\text { Kako s pomočjo komuniciranja stopiti iz sence? : How } \\
\text { to get out of the shadow with communication }\end{array}$ & \begin{tabular}{|l|} 
Zbornik 11. \\
slovenske \\
konference o \\
odnosih z javnostmi,
\end{tabular} & article \\
\hline 2007 & $\begin{array}{l}\text { Postuvan .V, Becaj } \\
\text { J., Marusic A. }\end{array}$ & $\begin{array}{l}\text { Nurses' attitudes towards depression: a study in } \\
\text { Slovenia. }\end{array}$ & Psychiatr Danub & article \\
\hline
\end{tabular}




\begin{tabular}{|c|c|c|c|c|}
\hline 2008 & $\begin{array}{l}\text { IVZ - Institute for } \\
\text { Public Health }\end{array}$ & Europski pakt za duševno zdravje in dobro počutje & pdf document & article \\
\hline 2008 & $\begin{array}{l}\text { Švab V., Zaletel } \\
\text { Kragelj L. }\end{array}$ & Mental health care & chapter in book & chapter \\
\hline 2008 & $\begin{array}{l}\text { Strbad M., Konecnik } \\
\text { N., Švab V. }\end{array}$ & Slovenska INDIGO študija : Slovene INDIGO study & $\begin{array}{l}\text { Program in zbornik } \\
\text { prispevkov (Program } \\
\text { and articles) }\end{array}$ & article \\
\hline 2008 & $\begin{array}{l}\text { Strbad M., Švab I., } \\
\text { Zalar B., Švab V. }\end{array}$ & $\begin{array}{l}\text { Stigma of mental illness: comparison of patients' and } \\
\text { students' attitudes in Slovenia }\end{array}$ & Zdrav Vest & article \\
\hline 2008 & $\begin{array}{l}\text { Mivsek AP., Hundley } \\
\text { V., Kiger A. }\end{array}$ & $\begin{array}{l}\text { Slovenian midwives' and nurses' views on post-natal } \\
\text { depression: an exploratory study }\end{array}$ & Int Nurs Rev & article \\
\hline 2008 & $\begin{array}{l}\text { Rifel J., Švab I., } \\
\text { Petek Šter M., Rotar } \\
\text { Pavlič D., King M., } \\
\text { Nazareth I. }\end{array}$ & $\begin{array}{l}\text { Impact of demographic factors on recognition of } \\
\text { persons with depression and anxiety in primary care } \\
\text { in Slovenia }\end{array}$ & BMC Psychiatry & article \\
\hline 2008 & $\begin{array}{l}\text { King M., Nazareth I., } \\
\text { Levy G., Walker C., } \\
\text { Morris R., Weich S. } \\
\text { et al. }\end{array}$ & $\begin{array}{l}\text { Prevalence of common mental disorders in general } \\
\text { practice attendees across Europe }\end{array}$ & Br J Psychiatry & article \\
\hline 2009 & $\begin{array}{l}\text { Hegerl U., } \\
\text { Wittenburg L. }\end{array}$ & $\begin{array}{l}\text { Focus on mental health care reforms in Europe: the } \\
\text { European alliance against depression: a multilevel } \\
\text { approach to the prevention of suicidal behavior }\end{array}$ & Psychiatr Serv & article \\
\hline 2009 & $\begin{array}{l}\text { Hegerl U., } \\
\text { Wittenburg L. et al. }\end{array}$ & $\begin{array}{l}\text { Optimizing suicide prevention programs and their } \\
\text { implementation in Europe (OSPI Europe): an } \\
\text { evidence-based multi-level approach }\end{array}$ & BMC Public Health & article \\
\hline 2009 & $\begin{array}{l}\text { Thornicroft G., } \\
\text { Brohan E. et al }\end{array}$ & $\begin{array}{l}\text { Global pattern of experienced and anticipated } \\
\text { discrimination against people with schizophrenia: a } \\
\text { cross-sectional survey }\end{array}$ & Lancet & article \\
\hline 2009 & $\begin{array}{l}\text { Trobec I., Herbst M., } \\
\text { Zvanut B. }\end{array}$ & $\begin{array}{l}\text { Differentiating between rights-based and relational } \\
\text { ethical approaches }\end{array}$ & Nurs Ethics & article \\
\hline 2009 & $\begin{array}{l}\text { Kersnik J., Poplas } \\
\text { Susic T., Kolsek M., } \\
\text { Svab I. }\end{array}$ & $\begin{array}{l}\text { What may stimulate general practitioners to undertake } \\
\text { screening and brief intervention for excess alcohol } \\
\text { consumption in Slovenia? A focus group study }\end{array}$ & J Int Med Res & article \\
\hline 2009 & Novak L. , Švab V. & $\begin{array}{l}\text { Antipsychotics side effects influence on stigma of } \\
\text { mental illness: focus group study results }\end{array}$ & Psychiatr Danub & article \\
\hline 2009 & Švab V. & Severe mental illness - patients' children needs & Psychiatr Danub & article \\
\hline 2010 & $\begin{array}{l}\text { Jeriček Klanšček H., } \\
\text { Zorko M., Bajt M., } \\
\text { Toškar S. (ed.) }\end{array}$ & Duševno zdravje v Sloveniji & book & book \\
\hline 2010 & $\begin{array}{l}\text { Scheerder G., } \\
\text { Audenhove CV. et al. }\end{array}$ & $\begin{array}{l}\text { Community and health professionals' attitude toward } \\
\text { depression: A pilot study in nine EADD countries }\end{array}$ & Int J Soc Psychiatry & article \\
\hline 2010 & $\begin{array}{l}\text { Subelj M., Vidmar G., } \\
\text { Svab V. }\end{array}$ & $\begin{array}{l}\text { Prescription of benzodiazepines in Slovenian family } \\
\text { medicine: a qualitative study }\end{array}$ & $\begin{array}{l}\text { Wien Klin } \\
\text { Wochenschr }\end{array}$ & article \\
\hline
\end{tabular}


Table 2. Other references.

Tabela 2. Objave v medijih.

\begin{tabular}{|c|c|c|c|c|}
\hline Year & Autor & Title & Source & $\begin{array}{l}\text { Type of } \\
\text { document }\end{array}$ \\
\hline 2002 & Šent & $\begin{array}{l}\text { Ljudje z duševnimi motnjami ne smejo biti } \\
\text { diskriminirani } \\
\text { http://www.dnevnik.si/novice/slovenija/33623 }\end{array}$ & $\begin{array}{l}\text { http://www.dnevnik.si/ } \\
\text { novice/slovenija/33623, }\end{array}$ & article \\
\hline 2002 & Matos U. & Tobogan razpoloženj & Mladina & article \\
\hline 2003 & Grah M. & $\begin{array}{l}\text { Na udaru so ljudje } z \text { roba: People from the } \\
\text { margins are under shock }\end{array}$ & Delo & article \\
\hline 2005 & Mayo & Mental IIIness and stigma: Coping with the ridicule & DAM www.nebojse.si & article \\
\hline 2005 & $\begin{array}{l}\text { IVZ - Institute for } \\
\text { Public Health }\end{array}$ & $\begin{array}{l}\text { Zakaj molčimo? Depresija :(Why are we silent? } \\
\text { Depression }\end{array}$ & ttp://www.zzv-ce.si & pamphlet \\
\hline 2005 & Potočnik K. & $\begin{array}{l}\text { Vsak dvajseti Korošec je depresiven : Every } \\
\text { twenty Korošec /local/ is depressed }\end{array}$ & Večer & article \\
\hline 2005 & $\begin{array}{l}\text { Marušič A., Mager } \\
\text { I. }\end{array}$ & Dr. Andrej Marušič - intervju & Dnevnik & interview \\
\hline 2005 & $\begin{array}{l}\text { IVZ - Institute for } \\
\text { Public Health }\end{array}$ & $\begin{array}{l}\text { Medijska Promocijska kampanja "Premagal } \\
\text { sem depresijo" : Media promotion campaign: "I } \\
\text { survived depression« }\end{array}$ & promotion campaign & $\begin{array}{l}\text { promotion } \\
\text { campaign }\end{array}$ \\
\hline 2006 & Šent & $\begin{array}{l}\text { Razpoloženjske (afektivne) motnje: Mood } \\
\text { (affective) disorders }\end{array}$ & Glasilo Šent & article \\
\hline 2006 & Pucelj V. & O depresiji : About Depression & http://www.zzv-ce.si & article \\
\hline 2007 & $\begin{array}{l}\text { Ažman R. , } \\
\text { Marinovič G }\end{array}$ & Petnajstletna vojna s seboj & 7 dni & article \\
\hline 2007 & $\begin{array}{l}\text { Ažman R., Lupša } \\
\text { M. }\end{array}$ & Potovanje na konec noči & Jana & article \\
\hline 2007 & $\begin{array}{l}\text { Lorenčič M., } \\
\text { Marušič A. }\end{array}$ & $\begin{array}{l}\text { Depresijo je treba zdraviti, ne pa samo iskati } \\
\text { razloge zanjo: We need to treat depression, not } \\
\text { only to search causes }\end{array}$ & Dnevnik & article \\
\hline 2007 & Ažman R. & Depra & book & book \\
\hline 2007 & DAM & $\begin{array}{l}\text { Gibanje za destigmatizacijo duševne bolezni in } \\
\text { duševnih motenj : Movement for destigmatization } \\
\text { of mental illness and mental disorders }\end{array}$ & www.nebojse.si & article \\
\hline 2008 & Cimerman M. & Nebojse.si & Viva & article \\
\hline 2008 & Kalc Furlanič L. & $\begin{array}{l}V \text { boju proti stigmatizaciji duševnih bolezni in } \\
\text { bolnikov : Fighting against stigma of the mentall ill }\end{array}$ & Primorske novice & article \\
\hline 2008 & Šent & $\begin{array}{l}\text { Pogled uporabnikov na težave } v \text { duševnem } \\
\text { zdravju: The view of consumers on mental health } \\
\text { problems }\end{array}$ & Glasilo Šent & article \\
\hline 2008 & Hrvatin J. & O psihosocialni rehabilitaciji na Debelem rtiču & Primorska info & article \\
\hline 2008 & Lampret $\mathrm{T}$. & $\begin{array}{l}\text { Samomor lahko prizadene vsakogar : Suicide can } \\
\text { affect anyone }\end{array}$ & www.delo.si & article \\
\hline
\end{tabular}




\begin{tabular}{|c|c|c|c|c|}
\hline 2008 & Snoj Z. & Depresija pri bolnikih z rakom & brochure & brochure \\
\hline 2009 & $\begin{array}{l}\text { Smith LL., Charles } \\
\text { H. Elliott }\end{array}$ & Depresija za telebane : Depression for Dummies & book & book \\
\hline 2009 & Fink C., Kraynak J. & $\begin{array}{l}\text { Bipolarna motnja za telebane : Bipolar Disorder } \\
\text { for Dummies }\end{array}$ & book & book \\
\hline 2009 & Švab V. & $\begin{array}{l}\text { Duševna bolezen in stigma : Mental Illness and } \\
\text { Stigma }\end{array}$ & book & book \\
\hline 2009 & Švab V., Knavs N. & $\begin{array}{l}\text { Duševnost } v \text { času krize: prilagodljivi, a ne } v \\
\text { nedogled : Mind in the time of crisis: adaptable, } \\
\text { but not unlimitedly }\end{array}$ & Dnevnik & article \\
\hline 2009 & $\begin{array}{l}\text { Švab V., Hadner } \\
\text { Hvala S. }\end{array}$ & $\begin{array}{l}\text { Polovica Slovencev bi potrebovala psihiatra :Half } \\
\text { of Slovene people should need mental health help }\end{array}$ & Žurnal24.si & article \\
\hline 2009 & Jelen M. & $\begin{array}{l}\text { Veliki koncert v spomin na delo Andreja Marušiča } \\
\text { : Big Concert in the Memory of Andrej Marušič }\end{array}$ & Primorska info & article \\
\hline 2009 & Radio Capris & $\begin{array}{l}\text { Koncert za destigmatizacijo depresije - ker } \\
\text { je depresija ozdravljiva bolezen! : Concert } \\
\text { for Destigmatization of Depression-because } \\
\text { depression is a curable disease! }\end{array}$ & www.radiocapris.si & $\begin{array}{l}\text { article and } \\
\text { concert }\end{array}$ \\
\hline 2009 & OZARA & $\begin{array}{l}\text { Gledališka igra Tunel, trgovina s samomorilskimi } \\
\text { pripomočki : Spector Tunel, shop with suicidal } \\
\text { devices }\end{array}$ & www.ozara.org, & $\begin{array}{l}\text { article and } \\
\text { theater } \\
\text { performance }\end{array}$ \\
\hline 2009 & Ručna N. & $\begin{array}{l}\text { Boj proti stigmatizaciji : Žurnal24.si Fight Against } \\
\text { Stigma }\end{array}$ & Žurnal24.si & article \\
\hline 2009 & N.N. & Se tudi vam zdi življenje brezupno? & 24ur.com & article \\
\hline 2009 & STA, SIOL & $\begin{array}{l}\text { Varovanja duševnega zdravja je izredno } \\
\text { kompleksno: Protecting Mental Health is a } \\
\text { Complex Task }\end{array}$ & www.nebojse.si & article \\
\hline 2009 & Valič M. & $\begin{array}{l}\text { O promociji duševnega zdravja : About mental } \\
\text { health promotion }\end{array}$ & www.nebojse.si & article \\
\hline 2009 & Kogoj A. & $\begin{array}{l}\text { Breme let - depresija v starosti : The burden of } \\
\text { age-depression in old age }\end{array}$ & ABC zdravja & article \\
\hline 2010 & $\begin{array}{l}\text { Valič M., Artnik } \\
\text { Knibbe T. }\end{array}$ & $\begin{array}{l}\text { Depresija - izmuzljiv objem notranje teme } \\
\text { Depression: slippy hug of inner darkness }\end{array}$ & Dnevnik.si & article \\
\hline 2010 & Jovandarič A. & $\begin{array}{l}\text { Duševne motnje - miti in predsodki : Mental } \\
\text { Disorders-Myth and Prejudice }\end{array}$ & http://www.n-tv.si & article \\
\hline 2010 & $\begin{array}{l}\text { IVZ - Institute for } \\
\text { Public Health }\end{array}$ & $\begin{array}{l}\text { Ni zdravja brez duševnega zdravja : No health } \\
\text { without mental health }\end{array}$ & Portal IVZ & article \\
\hline 2010 & Marn U. & $\begin{array}{l}\text { lzguba službe se v psihološkem doživljanju kaže } \\
\text { kot oblika žalovanja : Job loss represents as } \\
\text { mourning }\end{array}$ & Mladina & article \\
\hline
\end{tabular}

\subsection{NGO Programs against stigma}

The first anti-stigma report was published in 2000 predicting the development of an anti-stigma movement in Slovenia with the guidance of the NGOs, as one of them (ŠENT) in 1996 organized a series of public events to challenge stereotypes about mental illness. ŠENT started a public debate on the social position of people with mental disorders and their carers (2). One of the first round tables in the centre of Ljubljana about stigma and discrimination against mental illness was the launch of an anti-discrimination program in Slovenia, but with no financial resources at that time (3).

In 2002, one of the newspapers published an article on the depression of an NGO activist, psychologist and 
patient doctor Tanja Lamovec. The article covered her experience of depression and her personal strengths in coping with the illness. Therapeutic methods were presented (4). Other personal testimonies were published as a consequence $(5,6)$.

In 2004 the DAM Association was established, which quickly provided holistic web support (www.nebojse. si) with accessible information about depression and anxiety, self-help, service and practitioner contacts, literature, manuals, consultations and advice about medicines, psychotherapy, coping and self-help. A web forum, chat-room and blog forum were available from then on $(7,8)$.

In 2006 several debates and round tables organized by NGOs continued (9). DAM translated 'Mental Illness and stigma: Coping with the ridicule', an article explaining stigma, prejudice, discrimination and stereotypes (10). In 2007 a book on depression, DEPRA, was published by a journalist with personal experience of depression, Renata Ažman (11), which was followed by several public debates on depression and stigma. The call for the destigmatisation of depression started to be called the Movement Against Depression in several web reports (12). In 2008, the users' (consumers') organization called Mostovi (Bridges) was launched and opened a web page on the destigmatisation of mental disorders, calling for better professional mental health networks and psychiatric beds in general hospitals. Professionals, however, were their main speakers (13). NGO ŠENT organized an international EuroPsy Rehabilitation festival called 'Merry Go Round With Culture' with a strong empowerment mission for consumers of mental health services. The strongest emphasis was on fighting discrimination regarding employment $(14,15)$. Psychology students prepared a mental health promotion project 'How are you?'

In the same year, the president of DAM presented her own experience with depression and active involvement in self-help, education and empowerment for people with similar problems. DAM introduced its work as fighting against the stigma of depression and anxiety (15) and published in 2008 and 2009 several publications on coping with depression and anxiety, about self-help and treatment in a user-friendly way. Depression for Dummies and Bipolar Disorder for Dummies were published $(17,18)$.

In 2009, NGO ŠENT published the book by psychiatrist Vesna Švab, 'Mental IIIness and Stigma' (19), paying attention to various aspects of stigma and discrimination against people with various mental disorders and the results of the INDIGO study described below. This work was promoted in several web reports and journals (20).
One of the articles was connected to the infanticide of two children, which was presumed to have been by their 'mentally ill' mother (21). It led to improved reporting on this event.

In 2009 a big concert in memory of doctor Andrej Marušič, who launched the major movement of the anti-stigma depression campaign, was performed at the Slovenian coast. Depression was described as a curable disease in the frontlines of media reports (22, 23).

A comic drama on Slovene suicides was performed with the NGO OZARA, using comedy as a tool to fight stereotypes about suicide in Slovenia (24). Press conferences, round tables on destigmatising mental disorders and public events highlighting stereotypes on mental disorders continued $(25,26)$. A videospot / advert on the stigma of depression was created by NGO OZARA $(27,28)$. In 2010 an informative and personal report on depression from the perspective of Maja Valič, DAM president, was published (16).

\subsection{The organization of mental health care}

The problem of stigma was addressed in the research into how to organise mental health services in Slovenia, which included evidence based proposals for community treatment (29-31). In addition, The European Pact for mental health and wellbeing was published in 2008 under the Slovene presidency of the EU. The Green Paper on Mental Health was published in the web pages of The Institute for Public Health (IPH) (32). Depression, anxiety and suicide were identified as major public health problems in Slovenia at the round table organized to inform about the process of accepting a new National Mental Health Plan in Slovenia in 2009 $(33,34)$. Fighting against stigma is defined as one of the priorities in this still developing document. In the IPH publication Mental Health in Slovenia, depression and anxiety were identified as the most common mental health problems and the frequency of these disorders was identified and publicly presented (35). The major goals of the Slovenian mental health policy were identified (36).

\subsection{Suicide in Slovenia}

In 2003 the Suicide Attitudes Questionnaire (SUIATT) was sent to a representative sample of adult Slovenian citizens and $21.6 \%$ of them reported suicidal ideation (SI). More respondents with SI than respondents without SI reported: 1) the suicidal act as deliberated, 2) less importance attached to mental illness in suicidal behaviour, 3) that a person has the right to commit 
suicide, and 4) the suicidal act as an act of cowardice. Results did not allow a general statement of whether attitudes towards suicide are permissive or restrictive in Slovenia. However, in the subgroup of respondents with SI they found a tendency towards permissiveness regarding suicide (37).

In 2005, Slovene author doctor Andrej Marušič participated in analysis of risk factors for suicide and evidence-based prevention strategies. The study concluded that physician education in depression recognition and treatment, as well as restricting access to lethal methods, can reduce suicide rates. Other interventions need more evidence of efficacy. Ascertaining which components of suicide prevention programs are effective in reducing the rates of suicide and suicide attempts is essential in order to optimize the use of limited resources (38). This study influenced the prevention of suicide including destigmatisation in Slovenia in subsequent years and made way for the majority of public actions later. The stigma of suicide was discussed in two other articles by Slovenian authors about reducing suicide in Slovenia, and about mental health prevention $(39,40)$.

The first report on suicide reduction in Slovenia was also published in the media (41).

\subsection{EAAD, the European Alliance Against Depression}

The IPH was involved in anti-stigma research in 2004 by entering the EAAD project (European Alliance Against Depression, 2004-2008), with the leadership of dr. Andrej Marušič. The EAAD was active in 17 countries creating community-based networks using an evidencebased approach to improving care for depressed persons and preventing suicides. A shared multilevel approach was used that included interventions on four levels: the education of primary care physicians, a professional public relations campaign, training community facilitators and interventions with affected persons and high-risk groups. In 2009, EAAD reports were published (42-44). It was stressed that EAAD had broader destigmatising effects. Although the public campaigns focused on depression, their effects were likely to generalize to cover other areas of mental health. For the general population, the campaign was successful in creating campaign awareness for the Alliance Against Depression (Germany). For persons who reported experience with depression, analyses showed positive desirable effects, more positive attitudes towards medication treatment and also 'lack of selfdiscipline' declined as a causal explanation, as did the notion that people should 'pull themselves together'. The report on the education of primary care physicians (Slovene Gotland Study) was published on the IPH web page (45), and also in several newspapers. The project took place in two Slovenian regions with the cooperation of mental health NGOs. The goals of the project were to cooperate with family physicians, the public destigmatisation of depression, the education of professionals (such as social workers, pharmacists, priests and policemen) and to work on key parts of the population including self-help for people with depression. A publication containing information on depression for patients was published in 2005 and attached to the IPH web page (46). The media campaign 'I Survived Depression' was launched in 2005. Local government and non-government organizations supported EAAD by preparing public discussions and education seminars $(47,48)$. The campaign lasted for one month and used leaflets, TV and cinema spots and posters in public libraries, general practices, hospitals and centres for social work (49). Suicide reduction tried to be explained with closer look at antidepressant prescribing by GPS (50).

\subsection{International Study on Discrimination and Stigma Outcomes (INDIGO)}

Slovenia took part in the INDIGO international study (51), led by Professor Thornicroft, on perceived stigma and the discrimination of people with schizophrenia. A structured interview was completed with patients, using the Discrimination and Stigma Scale (DISC), which assessed experiences of being treated (dis) advantageously in several live domains. In Slovenia, 25 patients diagnosed with schizophrenia in outpatient settings were interviewed. The average levels of stigma and discrimination in Slovenia were comparable to other European countries. There are above average, if not statistically significant, levels of discrimination in employment, getting and keeping friendships, establishing a family, housing, getting and keeping a driving license and gaining social allowances. Overall, the diagnosis was a greater obstacle for schizophrenia patients in Slovenia than in other countries. But they nevertheless feel less discriminated against in education, regarding personal safety, marriage, divorce and parenting (52).

\subsection{Reports on education against stigma}

In 2002, stigma and discrimination were addressed in an article about supervision in mental health (53). In 2004, an International Conference on Education in 
Mental Health was organized in Nova Gorica, involving discussion and research reports on stigma among other educational issues (54). In 2007, an evaluation of Slovenian university students' attitudes towards patients with mental health problems was published, showing major differences between faculties and a lack of educational impact on students' attitudes towards psychiatric patients (55). The problem of self-stigma was reported through the research into prejudice regarding mental illness comparing university students and psychiatric patients, which revealed that patients stigmatise people with mental illness even more than the students (56). The first article about educating and communicating with the media to reduce stigma was published (57).

Medical nurses researched nurses' attitudes towards depression and tested the impact of education on these attitudes. They developed a questionnaire on attitudes towards depression using principal component analysis. Nurses had positive attitudes towards people with depressive disorder and towards curing and healing depression itself, but a somewhat neutral opinion on possible complications caused by depression. They concluded that overall, nurses' attendance at education workshops contributed to an improvement in their attitudes. This in turn probably led to a decrease in the stigmatisation of depression (58).

\subsection{Mental health professionals}

Mental health professionals have been involved in a range of articles and initiatives to develop the public and professional dialogue about stigma and mental illnesses over the last decade.

In 2002, the stigma of addiction disorders was addressed in the research by Bilban (59). In 2003, the biggest Slovenian journal published an interview with two psychiatrists aiming to reduce the stigma of severe mental disorders and informing readers about several groups of diagnoses linked to age and gender (60).

Four journal interviews with Andrej Marušič, who was leading the EAAD project on depression, treatment and overcoming prejudice were published in newspapers in 2005 (61). In these, European guidelines for stigma prevention were proposed. The Slovenian author Andrej Marušič took part in this work (62).

A handbook for teachers, students and researchers was published stressing the need for anti-stigma work in mental health environments (63).

Depression in the elderly population was addressed with an interview with the leading Slovene psychiatrist (64). Suicide in old age in Slovenia has been detected as a major mental health problem in the country.
Nurses published another article about attitudes in the nursing process to depressed patients (65). They also researched attitudes and approaches to involuntarily admitted patients and found that nurses emphasise the importance of ethics and personal values. The results indicate the importance of nurses' formal education, especially when caring for patients with mental illness (66).

Three brochures were published by a pharmaceutical company on depression and the connection of depression with somatic illness (coronary heart disease and cancer), with all three being available without charge in medical institutions (67).

Depression was connected to the economic crisis, personal stress and unemployment, increased use of psychiatric services and suicide in several newspapers interviewing psychiatrists (68).

Slovenian general practitioners addressed the problem of the discrimination against various marginalized groups as part of an international qualitative study with 233 general practitioners (GPs) in 11 countries and concluded that GPs should have adopted a more developed concept of patient involvement in their work (69). They also researched reasons for the under-use of screening and brief intervention early response (SBI) by healthcare professionals to their patients' alcoholrelated problems. This qualitative research study, which used focus group discussions with GPs to identify incentives that may increase the use of SBI in Slovene general practice, showed that besides other motivation, adequate knowledge, skills and record-keeping, as well as more extensive community action on the part of society as a whole e.g. government intervention, is needed to improve their working conditions (70).

In 2008 a report on factors influencing the early recognition of anxiety and depression in primary care was published (71). The results of two independent observational studies that were performed at the same time on a representative sample of family medicine practice attendees in Slovenia were compared. 10,710 patients participated in this Slovenian crosssectional survey (SCS) and 1118 patients in the first round of a cohort study (PREDICT-D study). Logistic regression was used to examine the effects of age, gender and educational level on the detection of depression and anxiety. A surprisingly low prevalence of major depression was found in PREDICT, especially considering the high rate of suicide and alcohol consumption previously reported in Slovenia (72). The problem of possible under-diagnosis was not discussed in these articles. 
The attitudes of GPs towards the patients' right to self-determination was researched and found to be less important than other values, e.g. the obligation to promote medical benefit, to protect from harm, to distribute public resources fairly and to enhance the patient-physician relationship (73).

Two other articles were published on stigma connected to the side effects of medication (74) and about stigma attached to the children of people with severe mental disorders (75).

\section{CONCLUSIONS}

The overview of Slovene research and public media reports on stigma and discrimination presents a lack of research into the known patterns of stigma and discrimination associated with depression (e.g. public surveys, controlled studies, patterns of stigma and discrimination in key settings, such as schools and workplaces), but relatively strong pointers for promising practice for effective interventions to reduce stigma and discrimination in relation to mental health problems and the strong involvement of NGOs and the National Institute for Public Health. Professionals, NGOs, individuals with personal experience of stigma and researchers are deeply interested in stigma, particularly regarding suicide, which is a major public health problem in Slovenia. The overview also shows an important media contribution to reducing stigma in this country and several examples of good practice. In spite of the lack of funds for programmes and research (except from short EAAD funding), a strong sensitivity for stigma issues is perceived, which might be culturally influenced. A systematic and growing amount of data on prevention activities is observed, influenced by international guidelines. We also perceived a very coordinated set of actions amongst the government institution (IPH) and NGOs with the participation of empowered individuals, even though supported with little or no resources. The relatively small population number that demands openness to other experience and praxis abroad and high commitment allows Slovenia to build strong anti-stigma campaigns. The National Plan for Mental Health in procedure right now should facilitate improvements to research, the evidence base and upgrade of this action.

Članek je nastal v okviru projekta Anti Stigma Programme European Network (ASPEN), ki ga financira Evropska unija.

\section{References}

1. Darovec J. Psihiatrija včeraj, danes, jutri. Zdrav Var 1992; 31: 5-9

2. Švab, V. Anti stigma program in Slovenia. Psychiatria Danub 12: $152-153$.

3. Dnevnik Slo 9. 10. 2002. Available 21.6.2010 from: http://www. dnevnik.si/novice/slovenija/33623.

4. Matos U. Tobogan razpoloženj. Mladina 2002. Available 24.6.2010: http://www.mladina.si/tednik/200233/clanek/ depresija/.

5. Ažman R, Marinovič G. Petnajstletna vojna s seboj. 7 dni 2007; 9: 10-12. Available 21.6.2010 from: http://www.depra.si/datoteke/ Intervju_7dni.pdf.

6. Ažman $R$, Lupša M. Potovanje na konec noči. Jana 2007; 2: 20-21. Available 21.6.2010 from: http://www.depra.si/datoteke/ jana_renata.pdf.

7. Cimerman M. Presentation of the Slovene Association for Persons Suffering from Depression and Anxiety Disorders. Medicinski razgledi 2006; 45 (Suppl 1): 37-40.

8. Cimerman M. Nebojse.si. Viva 2008. Available 24.6.2010 from: http://www.nebojse.si/portal/index.php?option=com_content\&ta sk=view\&id=361\&ltemid=2.

9. Šent. Razpoloženjske (afektivne) motnje: mood (affective) disorders. Glasilo Šent 2006. Available 21.6.2010 from: http:// prireditve.sent-si.org/REVIJA_SENT_06/2006-sent-05-web.pdf and http://www.viva.si/Psihiatrija/574/Shizofrenija.

10. DAM. Mayo Foundation for Medical Education and Research 2005. Mental illness and stigma: coping with the ridicule. Available 26.7.2010 from: http://nebojse.caprae.net/portal/index. php?option=com_content\&task=view\&id=65\&ltemid=99999999 \&date $=2012-09-01$.

11. Ažman R. Depra. Celje: Mohorjeva družba, 2007.

12. DAM. Gibanje za destigmatizacijo duševne bolezni in duševnih motenj. Portal www.nebojse.si 2007. Available 21.6.2010 from: http://www.nebojse.si/portal/index.php?option=com_content\&ta sk=blogcategory\&id=33\&ltemid $=55$.

13. Kalc Furlanič L. V boju proti stigmatizaciji duševnih bolezni in bolnikov. Primorske novice 2008. Available 21.6.2010 from: http://www.drustvomostovi.org/index.php?option=com_ content\&task=view\&id=25.

14. Šent. Pogled uporabnikov na težave v duševnem zdravju. Glasilo Šent 2008. Available 21.6.2010 from: http://europsy2008.sent. si/SENT_2008/sent_4_2008.pdf and http://euro-psy2008.sent. si/20_21.pdf and http://www.primorska.info/novice/1197/o_ psihosocialni_rehabilitaciji_na_debelem_rticu.

15. Hrvatin J. O psihosocialni rehabilitaciji na Debelem rtiču. Primorska info 24.9.2008. Available 21.6.2010 from: http:// www.primorska.info/novice/1197/o_psihosocialni_rehabilitaciji_ na_debelem_rticu

16. Valič M, Artnik Knibbe T. Depresija - izmuzljiv objem notranje teme. Dnevnik.si 2010. Available 24.6.2010 from: http://www. dnevnik.si/tiskane_izdaje/zdravje/1042338459.

17. Smith LL, Charles H. Elliott. Depresija za telebane. Ljubljana: Pasadena, 2009.

18. Fink C, Kraynak J. Bipolarna motnja za telebane. Ljubljana: Pasadena, 2009.

19. Švab V. Duševna bolezen in stigma. ŠENT 2009.

20. Švab V, Knavs N. Duševnost v času krize: prilagodljivi, a ne v nedogled. Dnevnik 2009. Available 21.6.2010 from: http://www. nebojse.si/portal/index.php?option=com_content\&task=view\&i $d=548 \&$ Itemid $=2$.

21. Švab V, Hadner Hvala S. Polovica Slovencev bi potrebovala psihiatra. Portal Žurnal24.si 2009. Available 21.6.2010 from: http://www.nebojse.si/portal/index.php?option=com_content\&t ask $=$ view\&id $=521 \&$ Itemid $=2$. 
22. Jelen M. Veliki koncert $v$ spomin na delo Andreja Marušiča. Portal Primorska info 2009. Available 24.6.2010 from: http:// primorska.info/novice/5466/veliki_koncert_v_spomin_na_delo_ andreja_marusica.

23. Radio Capris. Koncert za destigmatizacijo depresije - ker je depresija ozdravljiva bolezen! Portal Radia Capris 2009. Available 24.6.2010 from: http://www.radiocapris.si/index. php? $\mathrm{mpage}=2 \& \mathrm{~S}=1 \&$ Article $=10859$.

24. Ozara. Gledališka igra Tunel, trgovina s samomorilskimi pripomočki. Portal Ozara 2009. Available 24.6.2010 from: http:// www. ozara. org/?id=230.

25. Ručna N. Boj proti stigmatizaciji. Žurnal24.si 2009. Available 24.6.2010 from: http://www.zurnal24.si/primorska/boj-protistigmatizaciji-144605/clanek.

26. Jovandarič A. Duševne motnje - miti in predsodki. Portal N-TV 2010. Available 24.6.2010 from: http://www.n-tv.si/dusevnemotnje-miti-in-predsodki.

27. N-TV. Ko bolita duša in telo. N-TV 2010. Available 24.6.2010 from: http://www.n-tv.si/depresija-ko-bolita-dusa-in-telo; http:// www.slovid.com/depresija+ko+bolita+dusa+in+telo/86351/video.

28. M. K. Se tudi vam zdi življenje brezupno? 24ur.com 10.10.2009. Available 24.6. 2010 from: http://www.n-tv.si/depresija-ko-bolitadusa-in-telo; http://24ur.com/specialno/nega_in_zdravje/se-tudivam-zdi-zivljenje-brezupno.html.

29. Švab V, Tomori M. Mental health services in Slovenia. Int J Soc Psychiatry 2002; 78: 177-188.

30. Švab V, Tomori, M, Zalar B, Ziherl S, Dernovšek MZ, Tavčar R. Community rehabilitation service for patients with severe psychotic disorders: the Slovene experience. Int J Soc Psychiatry 2002; 4: 156-160.

31. Švab V. Preparing mental health reform in Slovenia. Int $\mathrm{J}$ Psychosoc Rehabilit 2003; 8: 5-9.

32. Inštitut za varovanje zdravja. Ljubljana 2009. Available 7.7. 2010 from: http://ec.europa.eu/health/mental_health/docs/ mhpact_sl.pdf.

33. SIOL.Varovanja duševnega zdravja je izredno kompleksno. Portal SIOL 2009. Available 21.6.2010 from: http://www.nebojse. si/portal/index.php?option=com_content\&task=view\&id=592\& Itemid $=2$.

34. Valič M. O promociji duševnega zdravja, 2009. Available 24.6.2010 from: http://www.nebojse.si/portal/index.php?option=com_conte nt\&task=view\&id=602\&ltemid=99999.

35. Jeriček Klanšček H, Zorko M, Bajt M, Toškar S. (ed.). Duševno zdravje v Sloveniji. Ljubljana: Inštitut za varovanje zdravja, 2010. Available 24.6.2010 from: http://www.nebojse.si/portal/index. php?option=com content\&task=view\&id=678\&ltemid $=2$.

36. Inštitut za varovanje zdravja. Ni zdravja brez duševnega zdravja. Portal IVZ 2010. Available 24.6.2010 from: http://87.118.66.107/ Planet/Mp.aspx? ni=11\&pi=5\&_5_id $=70 \&{ }_{2} 5_{-}$ Pagelndex=0\&_5_groupld $=179 \&$ \&_newsCategory $=\& \_5$ action $=$ ShowNewsFull\&pl=11-5.0.

37. Kocmur M, Dernovsek MZ. Attitudes towards suicide in Slovenia: a cross-sectional survey. Int J Soc Psychiatry 2003; 49: 8-16.

38. Mann JJ, Apter A, Bertolote J, Beautrais A, Currier D, Haas A, Hegerl U, Lonnqvist J, Malone K, Marusic A, Mehlum L, Patton G, Phillips M, Rutz W, Rihmer Z, Schmidtke A, Shaffer D, Silverman M, Takahashi Y, Varnik A, Wasserman D, Yip P, Hendin H. Suicide prevention strategies: a systematic review. JAMA 2005; 294: 2064-2074.

39. Mirjanic M, Zorko M, Marusic A. Samomor je preprecljiv! Kaj pa v Sloveniji? JAMA, Slovenska izdaja 2006; 14: 55-56.

40. Kamin T. Mental health promotion: a perspective from Slovenia. J Public Mental Health 2006; 5: 26-30.

41. Lampret T. Samomor lahko prizadene vsakogar. Delo.si 2008. Available 21.6.2010 from: http://www.delo.si/clanek/66869.
42. Hegerl U, Wittenburg L. Focus on mental health care reforms in Europe: The European Alliance Against Depression: a multilevel approach to the prevention of suicidal behaviour. Psychiatr Serv 2009; 60: 596-599.

43. Hegerl U, Wittenburg L, Arensman E, van Audenhove C, Coyne JC, McDaid D, van der Feltz-Cornelis CM, Gusmão R, Kopp M, Maxwell M, Meise U, Roskar S, Sarchiapone M, Schmidtke A, Värnik A, Bramesfeld A. Optimizing suicide prevention programs and their implementation in Europe (OSPI Europe): an evidencebased multi-level approach. BMC Public Health 2009; 23: 428. Available 21.6.2010 from: http://www.biomedcentral.com/14712458/9/428.

44. Scheerder G, Audenhove CV, Arensman E, Bernik B, Giupponi G, Horel AC, Maxwell M, Sisask M, Székely A, Värnik A, Hegerl U. Community and health professionals' attitude toward depression: a pilot study in nine EADD countries. Int J Soc Psychiatry. 2010. Ahead of print.

45. Pucelj V. O depresiji. Inštitut za varovanje zdravja, 2006. Available 24.6.2010 from: http://ivz.arhiv.over.net/index. php?akcija=novica\&n=952.

46. Inštitut za varovanje zdravja. Zakaj molčimo? Depresija. Inštitut za varovanje zdravja, 2005. Available 23.6.2010 from: http://www. zzv-ce.si/uploads/zakajmolcimo.pdf).

47. Potočnik K. Vsak dvajseti Korošec je depresiven. Večer 2005. Available 23.6.2010 from: http://www.eaad.net/enu/media/ Vecer_depresija_koroska_dravska_050512.pdf.

48. Marušič A, Mager I. Dr. Andrej Marušič - intervju. Dnevnik.si 2005. Available 21.6.2010 from: http://cm.dnevnik.si/tiskane_ izdaje/dnevnik/145494.

49. Inštitut za varovanje zdravja. Medijska promocijska kampanja „Premagal sem depresijo“, 2005. Available 21.6.2010 from: http:// www.nebojse.si/portal/index.php?option=com_content\&task=vie w\&id=57\&ltemid $=46$.

50. Subelj M, Vidmar G, Svab V. Prescription of benzodiazepines in Slovenian family medicine: a qualitative study. Wienn Klin Wochen 2011. Ahead of print.

51. Thornicroft G, Brohan E, Rose D, Sartorius N, Leese M \& the Indigo Study Group. Global pattern of experienced and anticipated discrimination against people with schizophrenia: a cross-sectional survey. Lancet 2009; 373: 408-405.

52. Strbad M, Konecnik N, Švab V. Slovenska INDIGO študija. In: Novak Šarotar B, Bon J, Pregelj P. (ed.). Program in zbornik prispevkov. Ljubljana: Psychiatrist Section at the Medical Dostors Association, 2008: 128.

53. Zorga S. Supervision: the process of life-long learning in social and educational professions. J Interprof Care 2002; 16: 265-276.

54. Mednarodna konferenca o izobraževanju in preventivi na področju duševnega zdravja, 27.-29. maj 2004, Nova Gorica, Slovenija. Izobraževanje za spremembo : zbornik konference Izobraževanje za spremembo. ŠENT - Slovensko združenje za duševno zdravje, 2004.

55. Zalar B, Strbad M, Svab V. Psychiatric education: does it affect stigma? Acad Psychiatry 2007; 31: 245-246.

56. Strbad M, Švab I, Zalar B, Švab V. Stigma of mental illness: comparison of patients' and students' attitudes in Slovenia. 2008, Available from: http://vestnik.szd.si/slo/letno2008.pdf.

57. Kamin T. Kako s pomočjo komuniciranja stopiti iz sence? Slovenija and public health. Kamin T, Drev A, Hrast I. In: Zbornik 11. slovenske konference o odnosih z javnostmi. Ljubljana: Ozara, 2007.

58. Postuvan V, Becaj J, Marusic A. Nurses' attitudes towards depression: a study in Slovenia. Psychiatr Danub 2007; 19: 61-67.

59. Bilban M, Bilban Jakopin C. Methadone maintenance treatment and drugs. Coll Antropol 2002; 26: 107-117. 
60. Grah M. Na udaru so ljudje z roba. Delo.si 5.7.2003. Available 24.6.2010 from: http://nebojse.caprae.net/portal/index. php?option=com_content\&task=view\&id=21\&ltemid=99999999 \&date $=2011-10-01$.

61. Lorenčič M, Marušič A. Depresijo je treba zdraviti, ne pa samo iskati razloge zanjo. Dnevnik 17. march 2005. Available 23.6.2010 from: http://www.andrejmarusic.org/index.php/novice/besedila/ intervjuji/3-depresijo-je-treba-zdraviti-ne-pa-samo-iskati-razlogezanjo.html.

62. Marusic A, Mirjanic M, Bernik B. Europe evolving towards a region of non-mental health stigma: promoting the public's health (Laaser U. Book review: promoting the public's health). J Public Health 2007; 15: 225-226. Available 24.6.2010 from: http://www. springerlink.com/content/r5u3464062j8k466/fulltext.pdf, 2007).

63. Švab V, Zaletel Kragelj L. Mental health care. In: Kovačič L, Zaletel Kragel L. (ed.). Management in health care practice : a handbook for teachers, researchers and health professionals. Lage: Hans Jacobs Publishing Company 2008: 562-588. Available from: http://biecoll.ub.uni-bielefeld.de/volltexte/2009/2145/pdf/ Dokument5_5.pdf.

64. Kogoj A. Breme let - depresija v starosti. ABC zdravja 2009. Available 21.6.2010 from: http://www.nebojse.si/portal/index. php?option=com_content\&task=view\&id $=611$ \&ltemid $=2$

65. Mivsek AP, Hundley V, Kiger A. Slovenian midwives‘ and nurses‘ views on post-natal depression: an exploratory study. Int Nurs Rev. 2008; 55: 320-326.

66. Trobec I, Herbst M, Zvanut B. Differentiating between rightsbased and relational ethical approaches. Nurs Ethics. 2009; 16: 283-291.
67. Snoj Z. Depresija pri bolnikih z rakom. Ljubljana: Krka, 2008. Available 21.6.2010 from: http://www.ezdravje.com/media/pdf/ vszvz/depresija_pri_bolnikih_z_rakom.pdf

68. Marn U. Izguba službe se v psihološkem doživljanju kaže kot oblika žalovanja. Mladina 2010. Available 24.6.2010 from: http://www.mladina.si/tednik/200915/izguba_sluzbe_se_v_ psiholoskem_dozivljanju_kaze_kot_oblika_zalovanja.

69. Bremberg S, Nilstun T, Kovac V, Zwitter M. GPs facing reluctant and demanding patients: analysing ethical justifications. Fam Pract 2003; 20: 254-261.

70. Kersnik J, Poplas Susic T, Kolsek M, Svab I. What may stimulate general practitioners to undertake screening and brief intervention for excess alcohol consumption in Slovenia? a focus group study. J Int Med Res 2009; 37: 1561-1569.

71. Rifel J, Švab I, Petek Šter M, Rotar Pavlič D, King M, Nazareth I. Impact of demographic factors on recognition of persons with depression and anxiety in primary care in Slovenia. BMC Psychiatry 2008; 8: 96.

72. King M, Nazareth I, Levy G, Walker C, Morris R, Weich S, et al. Prevalence of common mental disorders in general practice attendees across Europe. Br J Psychiatry 2008; 192: 362-367.

73. Wetzels R, Geest TA, Wensing M, Ferreira PL, Grol R, Baker R. GPs' views on involvement of older patients: an European qualitative study. Patient Educ Couns. 2004; 53: 183-188.

74. Novak L \& Švab V. Antipsychotics side effects influence on stigma of mental illness: focus group study results. Psychiatr Danub. 2009; 21: 99-102.

75. Svab V. Severe mental illness - patients ' children needs. Psychiatr Danub. 2009; 21: 142-145. 